\title{
Role of HIV co-receptor usage in viral pathogenesis and cure
}

Monique Nijhus

From Frontiers of Retrovirology: Complex retroviruses, retroelements and their hosts

Cambridge, UK. 16-18 September 2013

Binding of the viral envelope glycoprotein gp120 to a co-receptor (CCR5 or CXCR4) is essential for HIV entry into CD4+ host cells. HIV co-receptor tropism is mainly determined by the third hypervariable loop of the viral envelope (gp120-V3). The presence of positively charged amino acids in this V3-loop, especially at positions 11 and 25 , is associated with binding to a negatively charged region of the CXCR4 co-receptor, whereas a more neutrally charged V3-loop is associated with CCR5 co-receptor binding.

The majority of HIV infections appear to be due to CCR5-using 'R5' virus, which continues to predominate during the course of the infection. As time progresses however, about $50 \%$ of patients have a shift in their viral population to include a growing amount of CXCR4-using 'X4' virus. Although an R5 to X4 switch is strongly correlated with increased rates of disease progression, it remains largely unknown which factors are causing the switch. Viral and immunological factors involved in co-receptor switching will be discussed as well as the role of co-receptor usage in HIV cure strategies.

Published: 19 September 2013

doi:10.1186/1742-4690-10-S1-O43

Cite this article as: Nijhus: Role of HIV co-receptor usage in viral pathogenesis and cure. Retrovirology 2013 10(Suppl 1):043.
Submit your next manuscript to BioMed Central and take full advantage of:

- Convenient online submission

- Thorough peer review

- No space constraints or color figure charges

- Immediate publication on acceptance

- Inclusion in PubMed, CAS, Scopus and Google Scholar

- Research which is freely available for redistribution

University Medical Center Utrecht, Netherlands

(c) 2013 Nijhus; licensee BioMed Central Ltd. This is an Open Access article distributed under the terms of the Creative Commons 